Raf. J. Sci.,Vol.28, No.2 Special Issue for the Third Scientific Conference of Chemistry, pp.47-55, 2019

\title{
Spectrophotometric Determination of Mesalazine in Pharmaceutical Preparations by Diazotization and Coupling with 2,6- Dihydroxytoluene as a New Coupling Agent
}

\author{
Alaa T. Aziz \\ Saad H. Sultan* \\ Department of Chemistry/ College of Science/ University of Mosul \\ *E-mail:saad.hasani@yahoo.com
}

(Received 5/8/2018;Accepted 25/10/2018)

\begin{abstract}
A simple and sensitive spectrophotometric method is proposed for the determination of mesalazine (MZ) in some of its pharmaceutical preparations. The method is based on the diazotization of mesalazine by reaction with sodium nitrite in an acidic medium and then coupling of diazonium salt corresponding to mesalazine with 2,6-dihydroxytoluene reagent in basic medium to produce an intense orange colored water-soluble and stable azo-dye for at lest two hrs, and exhibits maximum absorption at $453 \mathrm{~nm}$. Beer's law is obeyed in the concentration range of 2.5-100 $\mu \mathrm{g}$ of mesalazine in a final volume of $10 \mathrm{ml}$ i.e., $0.25-10.0 \mathrm{ppm}$ with a molar absorptivity of $4.6 \times 10^{4}$ 1. $\mathrm{mol}^{-1} . \mathrm{cm}^{-1}$ and sandell sensitivity index of $0.00332 \mu \mathrm{g} . \mathrm{cm}^{-2}$. A relative error is -0.48 to -4.80 and relative standard deviation of \pm 0.01 to \pm 0.17 depending on the concentration level. The proposed method has been applied successfully to determine mesalazine in pharmaceutical preparations, tablets and suppositories.
\end{abstract}

Keywords: Mesalazine, diazotization and coupling, 2,6-dihydroxytoluene reagent spectrophotometry.

\section{القير الليف للميزالزن في المستحضرك الميدلانية بلأزوتة ولافترلنمع الكلثف 2، شنائي

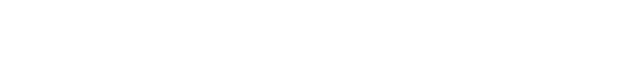

\section{الملغص}

يتضمن البحث اقتراحطريقةطيفية بسيطة ومسلسة لقدير الميزالازين في بعض مستحضرالته الصيدلانية. تعتمد الطريقة على أزوتة الميزالازين وذلك بتفاعله مع نتريت الصونيوم في الونط الحلمضي يتبعه اقتران ملح الدايازونيوم المقالل للميزالازين مع الكلثف 266 - ثنائي هيدروكسي تولوين في الوسط القاعدي لتكوين صبغة ازوية بررنقالية اللون ذائبة في الماء ومسقرة لمدة ساعتين على الأل وتعطي اعلى لمتصاص عند الطول الموجي453 نانوميتر. اطظق قانون بير في مدى الترلكيز 2.5 - 100 مايكروغرلم من الميزالازين في حهم نهائي 0 المللتر (0.25 - 10) جزء لكاعل لكل مليون، وكالت قيمة

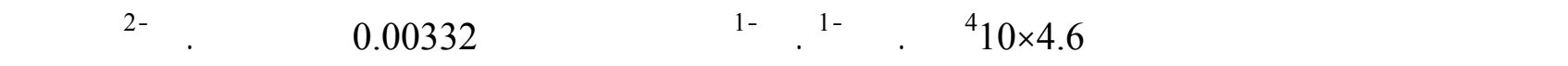
النبي من -0.48 المى -4.80 والانحراف القيلسي النسب بين الطريقة المقترحة بنجاح لقدير الميزالازين في الأفراص الدوائية والتحلميل.

الكاملت الدالة: الميزالازين، أزوتة واقتران، كلثف 6.2 - ثنائي هيدروكسي تولوين،طريقةطيفية. 


\section{INTRODUCTION}

Mesalazine (MZ), also known as mesalamine or 5-aminosalicylic acid (5-ASA), is an anti-inflammatory drug used to treat inflammation of the digestive tract (Crohn's disease) and mild to moderate ulcerative colitis (Kanala et al., 2013). Mesalazine is a first line drug for treatment of inflammatory bowel diseases. However, its mechanisms are not fully understood (Oh-oka et al., 2017). Mesalazine is a polar compound and it exhibits amphoteric properties (Nobilis et al., 2006), and chemically it is: 5-Amino-2-hydroxybenzoic acid and has the following chemical structure:

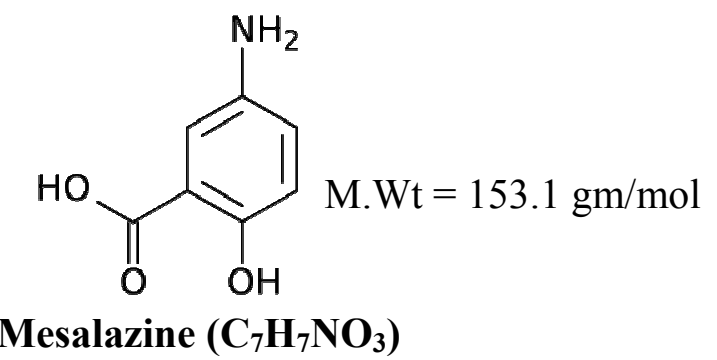

Mesalazine is a white or light grey or light pink powder or crystals, practically insoluble in alcohol, slightly soluble in water. It dissolves in dilute solutions of alkali hydroxides and in dilute hydrochloric acid (British pharmacopeia, 2013).

Several methods have been reported for determination of mesalazine in pure form or in pharmaceutical preparations. A spectrophotometric methods based on the diazotization and coupling reactions (zakaria, 2009; Dung et al., 2016), or based on the oxidative coupling reactions (Al-Fakhry, 2006; Salih and Al-Sharook, 2008; Shihab, 2011). Another spectrophotometric methods are based on formation of colored species (Al-Sabhaa and Habeeb, 2015) or by chargetransfer complex formation (Al-Enizzi et al., 2012) or by oxidation-reduction reactions (Hamdoon, 2018). Also UV spectrophotometric methods have been reported (Rao et al., 2015). The chromatographic methods for the determination of mesalazine include high performance liquid chromatography (Rao et al., 2013), and electrochemical methods for the determination of mesalizine based on cyclic voltammetry at a glassy carbon electrode (Kumar et al., 2017).

According to our knowledge and literature survey, the reagent 2,6-dihydroxytuluene has never been used in analytical chemistry. So, the aim of present work is the employing of this reagent for the determination of mesalazine in aqueous solution by diazotization and coupling reactions and application of proposed method to the pharmaceutical preparations.

\section{Instruments}

\section{EXPERIMENT}

All spectrophotometric measurements were carried out on Jasco V-630 UV-Visible spectrophotometer with $1.0 \mathrm{~cm}$ matched glass cells. $\mathrm{pH}$ measurements were performed by $\mathrm{pH}$ meter type TRANS BP 3001.

\section{Reagents}

All chemicals used are of analytical reagents grade.

\section{Standard solution of mesalazine $(100 \mu \mathrm{g} / \mathrm{ml})$}

This solution was prepared by dissolving $0.01 \mathrm{~g}$ of pure mesalazine (Aldrich) in $5 \mathrm{ml}$ ethanol and $40 \mathrm{ml}$ distilled water with gentle heating, then made up to the mark with distilled water.

\section{Working mesalazine solution $(25 \mu \mathrm{g} / \mathrm{ml})$}

A $25 \mathrm{ml}$ of $(100 \mu \mathrm{g} / \mathrm{ml})$ is diluted with distilled water to the mark in a $100 \mathrm{ml}$ volumetric flask.

\section{Hydrochloric acid solution (1N)}

This solution was prepared by diluting $8.6 \mathrm{ml}$ of the concentrated acid (Thomas Baker) to the mark with distilled water in a $100 \mathrm{ml}$ volumetric flask. 


\section{Sodium nitrite solution (1\%)}

This solution was prepared by dissolving $1.0 \mathrm{~g}$ of sodium nitrite (BDH) in $100 \mathrm{ml}$ distilled water in a volumetric flask.

\section{Sulphamic acid solution (1.5\%)}

This solution was prepared by dissolving $1.5 \mathrm{~g}$ of sulphamic acid (BDH) in $100 \mathrm{ml}$ distilled water in a volumetric flask.

\section{2,6-Dihydroxytoluene solution $(0.1 \%)$}

This solution was prepared by dissolving $0.1 \mathrm{~g}$ of 2,6-Dihydroxytoluene (Fluka) in $100 \mathrm{ml}$ distilled water.

\section{Sodium hydroxide solution (1M)}

This solution was prepared by the appropriate dilution of the concentrated volumetric (BDH) solution with distilled water and then transferred to a plastic bottle.

\section{Tablets (Pentasa and Awasalazine) solution $(25 \mu \mathrm{g} / \mathrm{ml})$}

The contents of 10 tablets (each tablet contains 500 or $400 \mathrm{mg}$ mesalazine as Pentasa or Awasalazine formulations) were finely powdered, mixed thoroughly and weighed accurately to an amount equivalent to $0.01 \mathrm{~g}$ of mesalazine and was dissolved in $5 \mathrm{ml}$ ethanol and $40 \mathrm{ml}$ distilled water with gentle heating and after filtration of the solution, the volume was completed to $100 \mathrm{ml}$ by distilled water in a volumetric flask. The working solution $(25 \mu \mathrm{g} / \mathrm{ml})$ was prepared by dilution.

\section{Suppositories (Asacol) solution $(25 \mu \mathrm{g} / \mathrm{ml})$}

The content of three Asacol suppositories (each one contains $500 \mathrm{mg}$ of mesalazine) are mixed well; an accurately weighed equivalent to $0.01 \mathrm{~g}$ of mesalazine was dissolved in $5 \mathrm{ml}$ ethanol and $40 \mathrm{ml}$ distilled water with gentle heating. After filtration of the solution, the volume was completed to $100 \mathrm{ml}$ by distilled water in a volumetric flask. The working solution $(25 \mu \mathrm{g} / \mathrm{ml})$ was prepared by appropriate dilution.

\section{Procedure and calibration graph}

Accurately measured volumes containing 2.5-100 $\mu \mathrm{g}$ of $\mathrm{MZ}$ were transferred into a series of $10 \mathrm{ml}$ calibrated flasks, followed by addition of $0.75 \mathrm{ml}$ of $1 \mathrm{~N}$ hydrochloric acid and $0.3 \mathrm{ml}$ of $1 \%$ sodium nitrite solution with occasional shaking and standing for $3 \mathrm{~min}$., a $0.5 \mathrm{ml}$ of $1.5 \%$ sulphamic acid solution is added with occasional shaking and standing for $3 \mathrm{~min}$. to remove the excess of sodium nitrite, $1 \mathrm{ml}$ of $0.1 \%$ 2,6-dihydroxytuluene reagent solution followed by addition of $2 \mathrm{ml}$ of $1 \mathrm{M} \mathrm{NaOH}$ and then the volumes are completed to the mark with distilled water; the absorbances are measured at $453 \mathrm{~nm}$ against the reagent blank solution. Beer's law is obeyed over the range of concentration 2.5 to $100 \mu \mathrm{g}$ of mesalazine/ $10 \mathrm{ml}(0.25-100 \mu \mathrm{g} / \mathrm{ml})$ and the concentration above $100 \mu \mathrm{g} / 10 \mathrm{ml}$ gives negative deviation Fig. (1). The apparent molar absorptivity referred to mesalazine has been found to be $4.6 \times 10^{4} 1 . \mathrm{mol}^{-1} \cdot \mathrm{cm}^{-1}$.

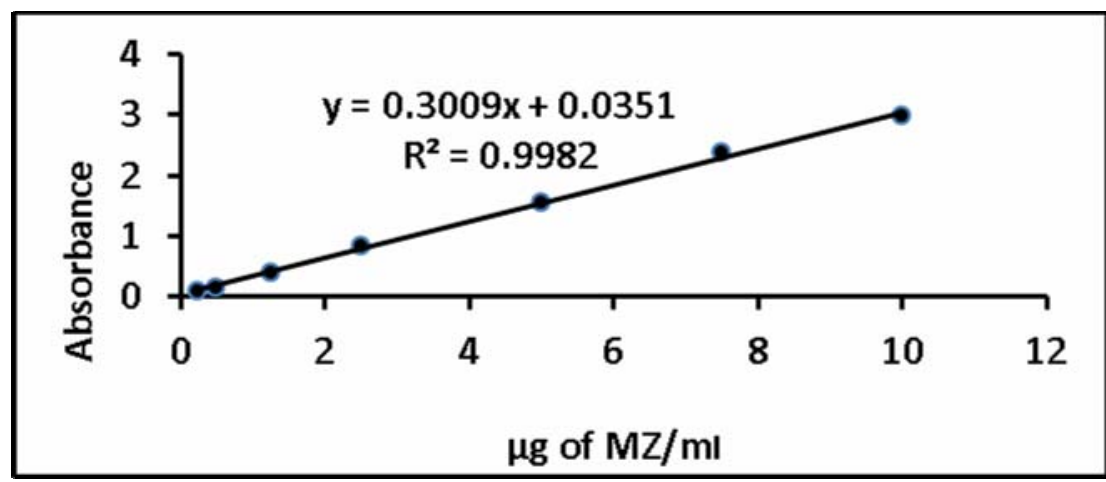

Fig. 1: Calibration graph for mesalazine determination using the proposed method

\section{RESULTS AND DISCUSSION}

During the investigation, $25 \mu \mathrm{g}$ of mesalazine was taken and the volumes are brought to $10 \mathrm{ml}$ with distilled water. 


\section{Principle of the method}

The first step for the determination, based on the reaction of mesalazine with excess nitrite in acidic medium to form the corresponding diazonium salt:

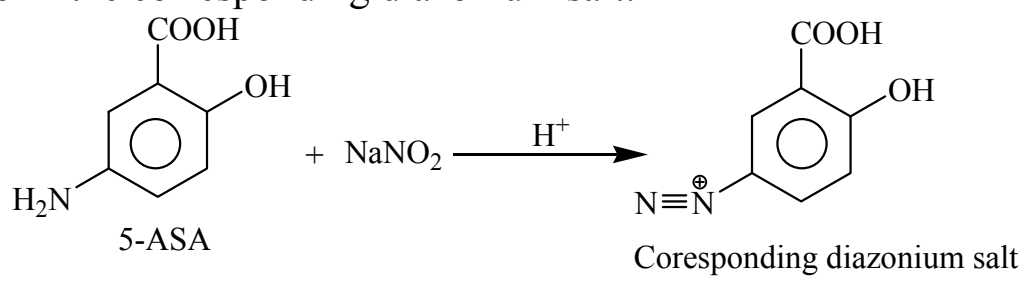

Then the corresponding diazonium salt was coupled with 2,6-Dihydroxytuluene in alkaline medium to form an intensely orange colored azo-dye:
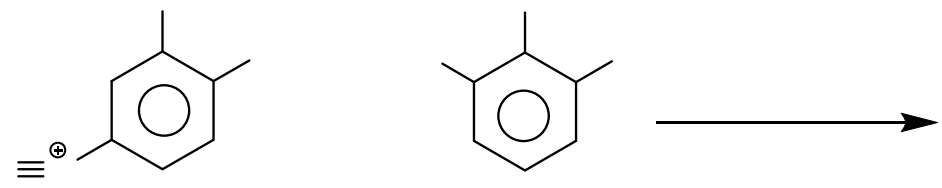

\section{Optimum reaction condition}

The effect of various parameters on the intensity of the colored product has been studied and optimum conditions have been selected.

\section{Effect of acid used for diazotization reaction}

The effect of quality and quantity of acid on the absorbance of the colored azo-dye was examined. The results shown in (Table 1) indicate that $0.75 \mathrm{ml}$ of $1 \mathrm{~N} \mathrm{HCl}$ is considered as an optimum volume; therefore, it was recommended for subsequent experiments.

Table 1: Effect of acid used for diazotization reaction

\begin{tabular}{|c|c|c|c|c|c|}
\hline \multirow[b]{2}{*}{ Acid used soln. (1N) } & \multicolumn{5}{|c|}{ Absorbance / $\mathrm{ml}$ of acid added } \\
\hline & 0.25 & 0.5 & 6.71 & 1.0 & 1.5 \\
\hline HCl & 0.5098 & 0.5472 & 0.6168 & 0.6023 & 0.5601 \\
\hline $\mathrm{HNO}_{3}$ & 0.5683 & 0.5914 & 0.5730 & 0.5100 & 0.4577 \\
\hline $\mathrm{H}_{2} \mathrm{SO}_{4}$ & 0.5461 & 0.5656 & 0.5947 & 05 至 & 0.5374 \\
\hline СН3СООН & 0.3824 & 0.4115 & 0.4276 & 0.3966 & 0.3806 \\
\hline
\end{tabular}

Effect of sodium nitrite amount and time

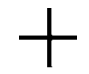

The diazotization process of mesalazine was investigated by addition of different amounts of $1 \% \mathrm{NaNO}_{2}$ solution for different times. Thesu res in (Table 2) indicate that complete diazotization of $\mathrm{MZ}$ occurs after $3 \mathrm{~min}$. when $0.3 \mathrm{ml}$ of $1 \% \mathrm{NaNO}_{2}$ solution is added because it gives maximum absorbance; therefore, it has been selectedforAssAquitazerinientin salt

Table 2: Effect of sodium nitrite amount and time

\begin{tabular}{|c|c|c|c|c|}
\hline \multirow{2}{*}{$\begin{array}{c}\text { ml of NaNO } \\
(\mathbf{1 \% )}\end{array}$} & \multicolumn{4}{|c|}{ Absorbance / standing time (min.) } \\
\cline { 2 - 5 } & $\mathbf{1}$ & $\mathbf{3}$ & $\mathbf{5}$ & $\mathbf{7}$ \\
\hline 0.1 & 0.3866 & 0.5129 & 0.4922 & 0.4441 \\
\hline 0.2 & 0.5033 & 0.5615 & 0.4990 & 0.4750 \\
\hline 0.3 & 0.5404 & 0.6210 & 0.6196 & 0.5428 \\
\hline 0.5 & 0.5271 & 0.5380 & 0.4750 & 0.4340 \\
\hline 0.7 & 0.4752 & 0.4857 & 0.4721 & 0.4301 \\
\hline
\end{tabular}




\section{Effect of sulphamic acid with the time}

The excess sodium nitrite must be removed by sulphamic acid because of its undesirable reactions (Clayden et al., 2001). The results in (Table 3) indicate that complete destruction of nitrite occurs after $3 \mathrm{~min}$. by addition of $0.5 \mathrm{ml}$ of $1.5 \%$ sulphamic acid solution.

Table 3: Effect of sulphamic acid with the time

\begin{tabular}{|c|c|c|c|c|c|c|}
\hline \multirow{2}{*}{$\begin{array}{c}\text { ml of sulphamic acid } \\
\text { soln.(1.5\%) }\end{array}$} & \multirow{2}{*}{ Variable } & \multicolumn{5}{|c|}{ Absorbance / Standing time (min.) } \\
\hline & & 1 & 2 & 3 & 4 & 5 \\
\hline \multirow{2}{*}{0.1} & $\mathrm{~S}$ & 0.0922 & 0.0931 & 0.3751 & 0.4580 & 0.3598 \\
\hline & $\mathrm{B}$ & 1.0928 & 1.8016 & 0.0251 & 0.0325 & 0.0352 \\
\hline \multirow{2}{*}{0.2} & $\mathrm{~S}$ & 0.2545 & 0.2999 & 0.4670 & 0.5772 & 0.3137 \\
\hline & $\mathrm{B}$ & 0.0439 & 0.0511 & 0.0305 & 0.0217 & 0.0388 \\
\hline \multirow{2}{*}{0.3} & $\mathrm{~S}$ & 0.4004 & 0.4579 & 0.5947 & 0.5872 & 0.4667 \\
\hline & $\mathrm{B}$ & 0.0362 & 0.0325 & 0.0268 & 0.0276 & 0.0304 \\
\hline \multirow{2}{*}{0.4} & $\mathrm{~S}$ & 0.3900 & 0.5325 & 0.5789 & 0.5640 & 0.4718 \\
\hline & $\mathrm{B}$ & 0.0301 & 0.0333 & 0.0266 & 0.0227 & 0.0300 \\
\hline \multirow{2}{*}{0.5} & $\mathrm{~S}$ & 0.4011 & 0.5956 & 0.6255 & 0.5813 & 0.4660 \\
\hline & $\mathrm{B}$ & 0.0366 & 0.0209 & 0.0200 & 0.0266 & 0.0335 \\
\hline \multirow{2}{*}{0.6} & $\mathrm{~S}$ & 0.5434 & 0.5058 & 0.5309 & 0.5547 & 0.4350 \\
\hline & $\mathrm{B}$ & 0.0267 & 0.0205 & 0.0287 & 0.0282 & 0.0355 \\
\hline
\end{tabular}

$\mathbf{S}=$ Sample $; \mathbf{B}=$ Blank

\section{Effect of reagent amount}

The coupling reaction between diazotized mesalazine and 2,6-dihydroxytoluene (DHT) reagent was investigated by adding different amount of reagent. From (Table 4), it can be observed that $1 \mathrm{ml}$ of $0.1 \%(2,6-\mathrm{DHT})$ is the more suitable amount which gives highest value of determination coefficient.

\section{Table 4: Effect of reagent amount}

\begin{tabular}{|c|c|c|c|c|c|c|}
\hline \multirow{2}{*}{$\begin{array}{c}\text { ml of } 0.1 \% \\
2,6-D H T \text { soln. }\end{array}$} & \multicolumn{5}{|c|}{ Absorbance / $\mu \mathrm{g}$ of mesalazine } & \multirow{2}{*}{$\mathbf{R}^{2}$} \\
\hline & 12.5 & 25 & 50 & 75 & 100 & \\
\hline 0.25 & 0.2510 & 0.5322 & 1.2205 & 1.8942 & 2.4578 & 0.9987 \\
\hline 0.5 & 0.2496 & 0.6285 & 1.1935 & 1.9638 & 2.4579 & 0.9956 \\
\hline 1.0 & 0.2433 & 0.6363 & 1.2657 & 1.8787 & 2.5412 & 0.9991 \\
\hline 1.5 & 0.2145 & 0.6356 & 1.2379 & 1.8700 & 2.4477 & 0.9977 \\
\hline 2.0 & 0.2402 & 0.5854 & 1.1894 & 1.9744 & 2.4688 & 0.9958 \\
\hline
\end{tabular}

\section{Effect of quality and quantity of base}

The preliminary experiment had shown that azo-dye formation occurs just in alkaline medium; so, the coupling reaction has been carried out with strong and weak bases. The results in (Table 5) show that sodium carbonate gave better sensitivity than sodium hydroxide and the formed azo-dye has a good stability; therefore, $2.5 \mathrm{ml}$ of $1 \mathrm{M} \mathrm{Na}_{2} \mathrm{CO}_{3}$ was selected for next experiments. 
Table 5: Effect of quality and quantity of base

\begin{tabular}{|c|c|c|c|c|c|c|}
\hline \multirow{2}{*}{$\begin{array}{l}\text { ml of base } \\
\text { used (1M) }\end{array}$} & \multicolumn{6}{|c|}{ Absorbance / $\mathrm{ml}$ of base added } \\
\hline & 0.5 & 1.0 & 1.5 & 2.0 & 2.5 & 3.0 \\
\hline \multicolumn{7}{|c|}{$\mathrm{NaOH}$} \\
\hline$\lambda \max$ & 470 & 487 & 485 & 487 & 490 & 491 \\
\hline $\mathbf{p H}$ & 4.90 & 12.14 & 12.56 & 12.70 & 12.84 & 13.17 \\
\hline A & 0.5662 & 0.6352 & 0.6843 & 0.6997 & 0.7034 & 0.6713 \\
\hline \multicolumn{7}{|c|}{ КОН } \\
\hline$\lambda \max$ & 407 & 454 & 472 & 482 & 487 & 490 \\
\hline pH & 4.64 & 9.49 & 12.39 & 12.83 & 13.05 & 13.16 \\
\hline $\mathbf{A}$ & 0.5111 & 0.6901 & 0.6812 & 0.6662 & 0.6852 & 0.6539 \\
\hline \multicolumn{7}{|c|}{$\mathrm{Na}_{2} \mathrm{CO}_{3}$} \\
\hline$\lambda \max$ & 452 & 452 & 453 & 452 & 453 & 453 \\
\hline pH & 5.85 & 8.95 & 9.64 & 10.61 & 10.16 & 10.20 \\
\hline $\mathbf{A}$ & 0.7176 & 0.7774 & 0.7782 & 0.7888 & 0.8256 & 0.8250 \\
\hline \multicolumn{7}{|c|}{$\mathrm{NaHCO}_{3}$} \\
\hline$\lambda \max$ & 440 & 442 & 448 & 453 & 454 & 454 \\
\hline pH & 1.59 & 5.98 & 6.51 & 6.89 & 6.92 & 7.05 \\
\hline $\mathbf{A}$ & 0.2116 & 0.3457 & 0.3428 & 0.3537 & 0.4919 & 0.5178 \\
\hline
\end{tabular}

\section{Effect of surfactants}

The obtained results from the investigation of three types of surfactants (CTAB, SDS and Triton X-100) on the sensitivity of proposed method revealed that there is no improvement in the intensity of the colored azo-dye. Therefore, it has been recommended to eliminate their use in the subsequent experiments.

\section{Effect of time on the color development}

The effect of time on color development of the formed azo-dye for two concentrations of MZ was investigated under the optimum experimental conditions. It has been noticed in (Table 6) that the azo-dye reached maximum absorbance immediately after the addition of the base, and stayed stable at least for $2 \mathrm{hrs}$. in which many measurements can be done.

Table 6: Effect of time on color development

\begin{tabular}{|c|c|c|}
\hline \multirow{2}{*}{ Time, minutes } & \multicolumn{2}{|c|}{ Absorbance / $\boldsymbol{\mu g}$ of MZ per 10 mI } \\
\cline { 2 - 3 } & $\mathbf{2 5}$ & $\mathbf{7 5}$ \\
\hline After dilution & 0.8294 & 2.3474 \\
\hline $\mathbf{5}$ & 0.8288 & 2.3470 \\
\hline $\mathbf{1 0}$ & 0.8279 & 2.3467 \\
\hline $\mathbf{1 5}$ & 0.8269 & 2.3458 \\
\hline $\mathbf{2 0}$ & 0.8264 & 2.3453 \\
\hline $\mathbf{2 5}$ & 0.8236 & 2.3450 \\
\hline $\mathbf{3 0}$ & 0.8220 & 2.3449 \\
\hline $\mathbf{3 5}$ & 0.8207 & 2.3448 \\
\hline $\mathbf{4 0}$ & 0.8196 & 2.3446 \\
\hline $\mathbf{4 5}$ & 0.8194 & 2.3440 \\
\hline $\mathbf{5 0}$ & 0.8190 & 2.3435 \\
\hline $\mathbf{5 5}$ & 0.8188 & 2.3421 \\
\hline $\mathbf{6 0}(\mathbf{1 h r}$ ) & 0.8189 & 2.3418 \\
\hline $\mathbf{1 2 0}(\mathbf{2 h r s . )}$ & 0.8145 & 2.3411 \\
\hline
\end{tabular}




\section{Final absorotion spectra}

The orange azo-dye formed between diazotized MZ and DHT in presence of sodium carbonate shows a maximum absorption at $453 \mathrm{~nm}$, while the reagent blank has a slight absorption at this wavelength Fig. (2).

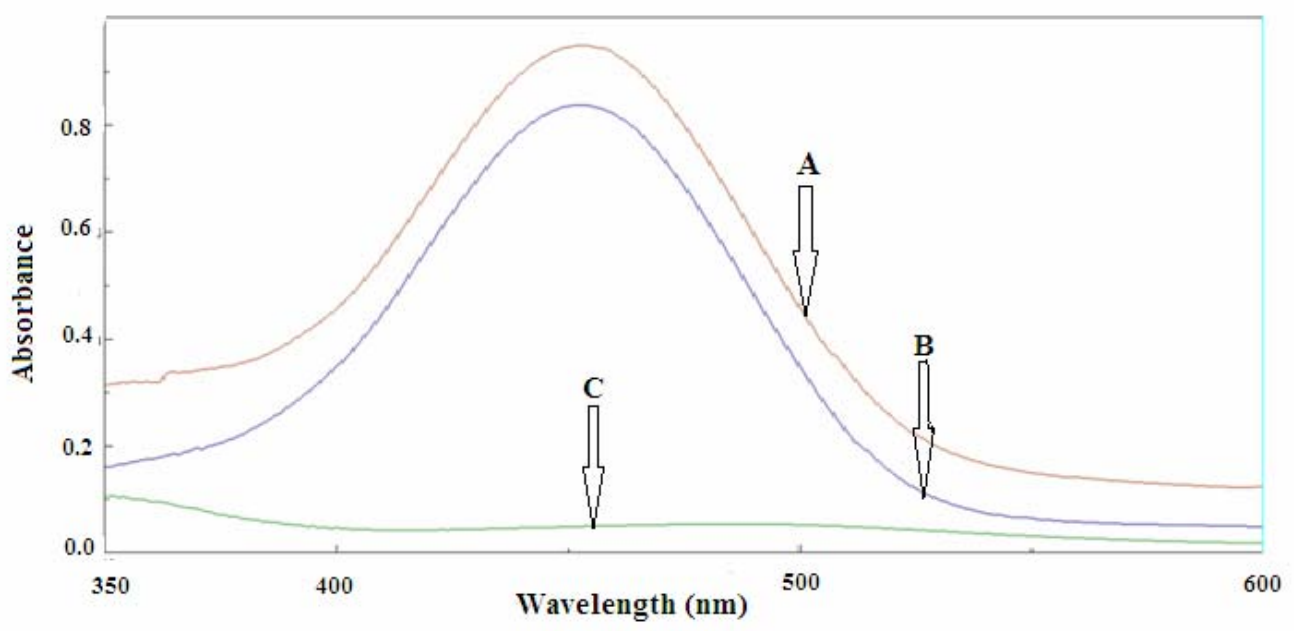

Fig. 2 : Absorption spectra of $25 \mu \mathrm{g}$ of $\mathrm{MZ} / 10 \mathrm{ml}$ treated according to the optimum conditions and measured against

(A) distilled water (B) blank (C) blank measured against distilled water

\section{Nature of the azo-dye}

To determine the reaction ratio of MZ to DHT reagent, Job's and mole-ratio methods have been applied. The results obtained indicate that the azo-dye has a composition ratio 1:1, hence it may have the following structure:<smiles>Cc1c([O-])ccc(/N=N/c2ccc([O-])c(C(=O)[O-])c2)c1[O-]</smiles>

Orange azo dye

\section{Interference of additives species}

The effect of some added compounds (excipients) which are often found in pharmaceutical preparations were studied by adding different amounts of this additives to $25 \mu \mathrm{g}$ of mesalazine using the recommended procedure and the results are given in (Table 7) indicating that none of added compounds can introduce significant interference.

\section{Table 7: Interference of additives species}

\begin{tabular}{|c|c|c|c|c|}
\hline \multirow{2}{*}{ Excipients } & \multicolumn{4}{|c|}{ Recovery (\%) } \\
\cline { 2 - 5 } & $\mathbf{1 0 0} \boldsymbol{\mu g}$ & $\mathbf{2 5 0} \boldsymbol{\mu g}$ & $\mathbf{5 0 0} \boldsymbol{\mu g}$ & $\mathbf{1 0 0 0} \boldsymbol{\mu g}$ \\
\hline starch & 97.6 & 99.1 & 99.3 & 98.3 \\
\hline Glucose & 97.7 & 98.3 & 98.7 & 97.7 \\
\hline Lactose & 97.3 & 97.6 & 98.2 & 97.3 \\
\hline Arabic gum & 97.6 & 97.7 & 98.6 & 97.4 \\
\hline
\end{tabular}

\section{Application of the Method}

To test the applicability of the proposed method, it has been applied to the determination of mesalazine in some of its pharmaceutical preparations (tablets and suppositories). The results which are shown in (Table 8) indicate that the proposed method has good accuracy, precision and recovery. 
Table 8: Application of the method

\begin{tabular}{|l|c|c|c|c|c|}
\hline \multicolumn{1}{|c}{$\begin{array}{c}\text { Pharmaceutical } \\
\text { preparation }\end{array}$} & $\begin{array}{c}\text { Amount } \\
\text { taken, } \boldsymbol{\mu g}\end{array}$ & $\begin{array}{c}\text { Amount } \\
\text { measured, } \\
\boldsymbol{\mu}\end{array}$ & $\begin{array}{c}\text { Recovery* } \\
\mathbf{( \% )}\end{array}$ & $\begin{array}{c}\text { Relative } \\
\text { error*, \% }\end{array}$ & $\begin{array}{c}\text { Relative } \\
\text { standard } \\
\text { deviation*,\% }\end{array}$ \\
\hline \multirow{2}{*}{$\begin{array}{l}\text { Pentasa, 500mg/tablet } \\
\text { (Ferring, Germany) }\end{array}$} & $\mathbf{1 2 . 5}$ & 12.02 & 96.16 & -3.84 & \pm 0.17 \\
\cline { 2 - 6 } & $\mathbf{2 5}$ & 24.80 & 99.20 & -0.80 & \pm 0.13 \\
\cline { 2 - 6 } & $\mathbf{7 5}$ & 72.79 & 97.05 & -2.94 & \pm 0.03 \\
\hline \multirow{2}{*}{$\begin{array}{l}\text { AwaSalazine, 400 mg/tablet } \\
\text { (Awamedica, Iraq) }\end{array}$} & $\mathbf{1 2 . 5}$ & 11.90 & 95.20 & -4.80 & \pm 0.02 \\
\cline { 2 - 6 } & $\mathbf{2 5}$ & 24.82 & 99.28 & -0.72 & \pm 0.03 \\
\hline $\begin{array}{l}\text { Asacol, 500mg/suppository } \\
\text { (Tillotts Pharma AG, }\end{array}$ & $\mathbf{7 5}$ & 72.68 & 96.90 & -3.09 & \pm 0.06 \\
\cline { 2 - 6 } Switzerland) & $\mathbf{1 2 . 5}$ & 11.91 & 95.28 & -4.72 & \pm 0.13 \\
\cline { 2 - 6 } & $\mathbf{2 5}$ & 24.88 & 99.52 & -0.48 & \pm 0.05 \\
\hline
\end{tabular}

*Average of five determinations

\section{Evaluation of proposed method}

The performance of the proposed method was checked by estimation of t-test compared with the standard method (Potentiometric titrations, British Pharmacopeia, 2013) for 95\% confidents level with eight degrees of freedom. The results in (Table 9) showed that the t-value was less than the critical value, which mean there is no significant difference between the present method and standard method for determination of mesalazine.

Table 9: Evaluation of proposed method by t-test analysis

\begin{tabular}{|l|c|c|c|}
\hline \multicolumn{1}{|c|}{ Pharmaceutical preparation } & \multicolumn{2}{|c|}{ Recovery $^{*}$ (\%) } & \multirow{2}{*}{ t-test (experimental) $^{\text {Standard method }}$ (ex $^{* *}$} \\
\cline { 2 - 3 } $\begin{array}{l}\text { Pentasa, 500 mg/tablet } \\
\text { (Ferring,Germany) }\end{array}$ & 97.06 & 98.29 & \pm 0.206 \\
\hline $\begin{array}{l}\text { AwaSalazine,400 mg/tablet } \\
\text { (Awamedica,Iraq) }\end{array}$ & 99.27 & 102.57 & \pm 0.704 \\
\hline $\begin{array}{l}\text { Asacol, 500mg/suppository } \\
\text { (Tillotts Pharma AG, Switzerland) }\end{array}$ & 96.87 & 99.51 & \pm 0.436 \\
\hline
\end{tabular}

*Average of five determinations

**Bitish pharmacopeia method (2013)

\section{Comparison with other spectrophotometric methods}

The proposed method has been compared favorably with other reported spectrophotometric methods. As shown in (Table 10), the proposed method is more sensitive with acceptable widthscale compared with other mentioned methods.

Table 10: Comparison with other spectrophotometric methods

\begin{tabular}{|c|c|c|c|}
\hline Analytical parameters & Present method & $\begin{array}{c}\text { Literature } \\
\text { method" }^{*}\end{array}$ & $\begin{array}{l}\text { Literature } \\
\text { method }^{* *}\end{array}$ \\
\hline Reagent & 2,6-DHT & Resorcinol & Pyrocaticol \\
\hline Medium of reaction & Aqueous & Aqueous & Aqueous \\
\hline pH & 10.16 & 12.38 & ---- \\
\hline Temperature & R.T & R.T & R.T \\
\hline Development time, (min.) & After dilution & 10 & 15 \\
\hline$\lambda_{\max }(\mathrm{nm})$ & 453 & 471 & 530 \\
\hline Beer's law range $\left(\mu \mathrm{g} \cdot \mathrm{ml}^{-1}\right)$ & $0.25-10$ & $0.4-12$ & $0.4-10$ \\
\hline Molar absorptivity $\left(1 . \mathrm{mol}^{-1} . \mathrm{cm}^{-1}\right)$ & $4.6 \times 10^{4}$ & $2.9 \times 10^{4}$ & $0.36 \times 10^{4}$ \\
\hline Stability of the dye (hr.) & 2 (at least) & 1 & $1 / 2$ \\
\hline Colour of the dye & Orange & Orange & Purple-red \\
\hline Application of the method & $\begin{array}{c}\text { Tablets and } \\
\text { suppositories }\end{array}$ & Capsules & $\begin{array}{c}\text { Tablets and } \\
\text { capsules }\end{array}$ \\
\hline
\end{tabular}

*(Zakarria, 2009);**(Shihab, 2011) 


\section{CONCLUSION}

A simple, rapid and sensitive spectrophotometric method was described for the determination of mesalazine in aqueous solution. The method was based on diazotization-coupling reactions to produce orange azo-dye which is water-soluble and stable for at least $2 \mathrm{hrs}$. The proposed method doesn't need temperature control or extraction process, and was applied successfully for the assay of mesalazine in its pharmaceutical preparations.

\section{REFERENCES}

Al-Enizzi, M.S.; Al-Sabhaa, T.N.; Al-Ghabsha, T.S. (2012). Use of charge transfer complex formation reaction in spectrophotometric microdetermination of some drugs. Jordan J. Chem., 7(1), 87-102 .

Al-Fakhry, M.H.A. (2006). The use of oxidative coupling reaction for spectrophotometric determination of aniline and its substituents and the drugs dipyrone and mesalazine. MSc. Thesis, Department of Chemistry. College of Education for Pure Science, University of Mosul, $64 \mathrm{p}$.

Al-Sabbah, T.N.; Habeeb, N.N. (2015). Spectrophotometric determination of mesalazine using sodium nitroprusside as chromogenic reagent. Eur. Chem. Bull., 4(8), 384-388.

"British pharmacopoeia" (2013). CD-Rom. Ed. System Simulation Ltd., the stationary office, London.

Clayden, J.; Greeves, N.; Warren, S.; Wothers, P. (2001). "Organic Chemistry". $2^{\text {nd }}$ ed., Oxford University Press, London, pp. 1056-1057.

Dung, N.T.; Anh, N.T.L.; Onah, D.T.; Dung, N.H. (2016). Development of spectrophotometric method for determination of mesalazine in pharmaceutical preparation. Vietnam J. Chem., 54(4), 509-514.

Hamdoon, E.A. (2018). Indirect spectrophotometric determination of mesalazine via chromate-1,5diphenylcarbazide complex. Raf. J. Sci., 27(3), 69-78.

Kanala, K.; Hwisa, N.T.; Chandn, B.R.; Mukkanti, K. (2013). Study of mesalazine $400 \mathrm{mg}$ tablets in Indian healthy volunteers under fasting conditions. Der. Pharm. Let., 5(3), 465-471.

Kumar, A.A.; Rani, T.S.; Ganesh, P.S.; Swamy, B.E.K. (2017). Electrochemical oxidation of mesalazine drug at poly (glutamic acid) modified glassy carbon electrode. Anal. Bioanal. Electrochem., 9(3), 328-339.

Nobilis, M.; Vybiralova, Z.; Sladkova, K.; Lisa, M.; Holcapek, M.; Kvetina, J. (2006). Highperformance liquid-chromatographic determination of 5-aminosalicylic acid and its metabolites in blood plasma. J. Chromatogr. A., 111(1-2), 299-308.

Oh-oka, K.; Kojima, Y.; Uchid, K.; Yoda, K.; Ishimaru, K.; Nakajima, S.; Hemmi, J.; Kano, H.; Fujii-Kuriyama, Y.; Katoh, R.; Ito, H.; Makao, A. (2017). Induction of colonic regulatory T cells by mesalamine by activating the aryl hydrocarbon receptor. Cel. Molec. Gastro. Hapto., 4(1), 135-151.

Rao, K.H.; Rao, A.L.; Sekhar, KB.C. (2013). Validated RP-HPLC method estimation of mesalazine in bulk and tablet dosage from. Inter. J. Res. Pharm. Chem., 3(2), 472-476 .

Rao, R.N.; Reddy, L.S.; Reddy, E.P.; Ravisankar, V.; Sulakshana, S.; Meenakshi, R. (2015). Spectrophotometric method development and validation for the estimation of mesalazine in pure and tablet dosage form by UV- spectrophotometric method. Inter. J. Pharm. Res. Scho., 4(4), 88-92.

Salih, E.S.; Al-Sharook, M.M. (2008). Spectrophotometric assay of mesalazine via oxidative coupling reaction with thymol and sodium metaperiodate. J. Ed. Sci., 21(1), 103-115.

Shihab, I.A. (2011). Spectrophotometric determination of mesalazine via oxidative coupling reaction. Tikrit J. Pur. Sic., 16(4), 64-69.

Zakaria, R.A. (2009). Spectrophotometric determination of mesalazine by diazotizationcoupling method with resorcinol. J. Raf. Sci, 20(1), 90-104. 